\title{
$\mathrm{Na}_{2}$-EDTA Test as a Stimulation Test for Parathyroid Hormone Secretion
}

\section{Takuo FUJITA}

Department of Geriatrics, University of Tokyo Faculty of Medicine

Intravenous infusion of $3.75 \mathrm{mg} / \mathrm{kg} \mathrm{Na}{ }_{2} \mathrm{EDTA}$ along with $4 \mathrm{mg} / \mathrm{kg}$ procaine resulted in a difinite fall of serum calcium which gradually recovered towards the previous level in endocrinologically and metabolically normal subjects with the expected time of recovery of 5.4 \pm 0.4 hours and a rise of serum immunoreactive parathyroid hormone by about 5 times. In postoperative and idiopathic hypoparathyroidism, on the other hand, the rerecovery of serum calcium was delayed, with prolongation of the expected time of recovery and scarecely any rise of serum parathyroid hormone. Na2-EDTA appears to be useful to stimulate the parathyroid hormone secretion and to test the functional reserve of the parathyroid glands in man.

(See pp. 1171 1175) 


\section{副甲状腺ホルモン分泌刺激試験としての}

\section{$\mathrm{Na} 2$-EDTA 負荷試験}

東京大学医学部老年病学教室

藤田拓男

(昭和 49 年 5 月13日受付)

$3.75 \mathrm{mg} / \mathrm{Na}_{2}$-EDTA を $4 \mathrm{mg} / \mathrm{kg}$ のプロカインとともして点滴静注すると血清カルシウムは明瞭に低下 を示し, 内分泌代謝機能に異常のみとめられない正常者では, 3 時間後の血清カルシウムの回復から推 定される期待回復時間は5.4 \pm 0.4 時間であり, 又血清副甲状腺ホルモンは $0.4 \pm 0.02 \mathrm{ng} / \mathrm{ml}$ から $1.8 \pm$ $0.21 \mathrm{ng} / \mathrm{ml}$ まで約 5 倍に上昇した。術後及び特発性副甲状腺機能低下症では, 期待回復時間の延長が見 られ，血清副甲状腺ホルモンの上昇は殆ど見られず，1例で正常值に達したのみであつた。 $\mathrm{Na}_{2}$-EDTA は血清カルシウムを低下せしめ副甲状腺ホルモンの分泌を刺激し, 副甲状腺予備能の検査に有用である と思われる。

\section{はじめに}

副甲状腺ホルモンの radioimmunoassay が行われる様になってから所謂副甲状腺機能恰查法の意義は大 きく変つて来た様である。即ち第一にに考えられることは今や直接副甲状腺ホルモンの測定が可能になつた ので副甲状腺ホルモンの血中及び尿中カルシウム燐なでに対する効果を見る間接的な副甲状腺機能検查の重 要性は減少したのではないかということである。しかし乍ら現在尚いなりの困難があり, 又色々な研究者に よつて同一の結果の得られていない副甲状腺ホルモンの radioimmunoassay だけでは臨床的に最終的に信 頼し得る検查とは考学られないという考え方も可能であり, 更に immunoreactive な副甲状腺ホルモンと biologically active な副甲状腺ホルモンが必ずしも同一のものではないととを考えると radioimmunoassay にも限界があることは明きらかであり，てのととからも間接的ではあつても副甲状腺ホルモンの人体に対す る作用に基づく副甲状腺機能検查法の重要性は失われないと考元られる。更に又副甲状腺ホルモンの radioimmunoassay の鋭敏さと，副甲状腺㙨能険査法の動的機能性の長所を活かして，両者を併用するととは極 めて有利であろう。

本報に於ては，乙の様な立場から，副甲状腺機能検查法の中でも副能甲状腺ホルモン分泌刺激法として独 自の位置を占める EDTA 負荷試験について著者の経験を述べるとともに，EDTAの血中副甲状腺ホルモ ンに対する効果を検討して EDTA 試験の診断的価値について考えてみたい.

\section{材料及び方法}

<症例 > 内分泌及び代謝異常を有しない副甲状腺機能正常之思われるもの18例，術後副甲状腺機能低下 症 5 例, 特発性副甲状腺機能低下症 5 例について EDTA- $\mathrm{Na}_{2}$ 負荷試験を行つた。

<検查> 体重 $1 \mathrm{~kg}$ 亿ついて $37.5 \mathrm{mg} の \mathrm{Na}_{2}$-EDTA (7.5\% Na -EDTA 水溶液（第 1 化学） $0.5 \mathrm{ml} / \mathrm{kg}$ ） に血管痛を防止するために $4 \mathrm{mg} / \mathrm{kg}$ のプロカイン（2\%プロカイン水溶液 $0.2 \mathrm{ml} / \mathrm{kg}$ ）を加え $200 \mathrm{ml}$ の\% ブドウ糖溶液中に溶解し, 約 20 分かけて点滴静注する. 点滴前及び終縮 5 分, 1 時間, 2 時間, 3 時間で採 
血し, 血清カルシウムは OCPD 色素法, 血清副甲状腺ホルモンはモルモットの抗牛副甲状腺ホルモン抗体 と ${ }^{125} \mathrm{I}$ 標識高度精製牛副甲状腺ホルモン（Wilson 社）を用い， dextran coated charcoal で B と F を分離す る方法で行つた ${ }^{122) 3}$. 期待回復時間は EDTA 点滴前に比較して点滴直後の血清カルウムの低下值で, てれ 飞比較して 3 時間後の回復值を除く，直線的に回復がつづくと仮定して投与前值に回復すると期待される時 間を期待回復時間として次の如く計算しだ)5.

$$
\text { 期間回復時間 }=\frac{\frac{3}{\text { EDTA による血清カルシウム低下 } \mathrm{mg} / \mathrm{dl}}}{3 \text { 時間後の回復值 } \mathrm{mg} / \mathrm{dl}}
$$

$$
\text { 結 果 }
$$

表 1 亿示す如く各年令の副甲状腺機能正常者10例では， $\mathrm{Na}_{2}$-EDTA によつて血清カルシウムは直ちに下

\begin{tabular}{|c|c|c|c|c|c|c|c|c|c|c|}
\hline \multirow{2}{*}{$\begin{array}{l}\text { Case } \\
\text { No. }\end{array}$} & \multirow{2}{*}{ Name } & \multirow{2}{*}{ Age } & \multirow{2}{*}{ Sex } & \multirow{2}{*}{ Diagnosis } & \multicolumn{5}{|c|}{ Serum $\mathrm{Ca} \mathrm{mg} / 100 \mathrm{ml}$} & \multirow{2}{*}{ ETR hr } \\
\hline & & & & & Before & $5 \mathrm{~min}$ & $60 \mathrm{~min}$ & ${ }_{\min }^{120}$ & $\left|\begin{array}{c}180 \\
\min \end{array}\right|$ & \\
\hline 1 & T.S. & 62 & $\mathrm{~F}$ & Normal & 9.0 & 7.5 & 7.6 & 8.1 & 8.1 & 7.5 \\
\hline 2 & K.M. & 56 & $\mathrm{~F}$ & " & 9.2 & 8.5 & 8.5 & 8.9 & 9.0 & 4.2 \\
\hline 3 & $\mathrm{Y} . \mathrm{K}$. & 57 & M & " & 10.0 & 8.6 & 8.7 & 9.5 & 9.3 & 6.0 \\
\hline 4 & T.N. & 36 & M & " & 9.3 & 8.7 & 8.6 & 8.6 & 9.0 & 6.0 \\
\hline 5 & M. K. & 50 & M & " & 9.6 & 8.8 & 9.0 & 9.1 & 9.3 & 4.8 \\
\hline 6 & Y.A. & 55 & M & " & 8.4 & 7.3 & 7.3 & 8.0 & 8.1 & 4.1 \\
\hline 7 & S.A. & 37. & $\mathbf{M}$ & " & 8.8 & 7.9 & 7.9 & 8.1 & 8.4 & 5.4 \\
\hline 8 & S.O. & 47 & $\mathbf{M}$ & " & 8.8 & 8.0 & 8.2 & 8.5 & 8.6 & 4.0 \\
\hline 9 & K. I . & 48 & $\mathbf{M}$ & " & 9.1 & 8.3 & 8.6 & 8.6 & 8.7 & 6.0 \\
\hline 10 & S.K. & 53 & M & " & 10.0 & 8.1 & 8.6 & 8.9 & 9.0 & 6.3 \\
\hline \multicolumn{4}{|c|}{ Mean \pm S.E.M. } & & $\begin{array}{r}9.2 \pm \\
0.2\end{array}$ & $\begin{array}{l}8.2 \pm \\
0.1\end{array}$ & $\begin{array}{l}8.3 \pm \\
0.2\end{array}$ & $\begin{array}{c}8.6 \pm \\
0.1\end{array}$ & $\begin{array}{r}8.8 \pm \\
0.1\end{array} \mid$ & $\begin{array}{l}5.4 \pm \\
0.4\end{array}$ \\
\hline
\end{tabular}
降し， 3 時間の経過で次第して投与前值に回復して期待復時間としては $5.4+0.4$ 時間となるに比し，表 2 亿

Table 1. Recovery of Serum Calcium in $\mathrm{Na}_{2}$-EDTA Test (Normal Subjects)

\begin{tabular}{|c|c|c|c|c|c|c|c|c|c|c|}
\hline \multirow{2}{*}{$\begin{array}{l}\text { Case } \\
\text { No. }\end{array}$} & \multirow{2}{*}{ Name } & \multirow{2}{*}{ Age } & \multirow{2}{*}{ Sex } & \multirow{2}{*}{ Diagnosis } & \multicolumn{5}{|c|}{ Serum $\mathrm{Ca} \mathrm{mg} / 100 \mathrm{ml}$} & \multirow{2}{*}{ ETR hr } \\
\hline & & & & & Before & $5 \mathrm{~min}$ & $60 \mathrm{~min}$ & $\mid \begin{array}{c}120 \\
\min \end{array}$ & $\left|\begin{array}{c}180 \\
\min \end{array}\right|$ & \\
\hline 1 & $\mathrm{~K} . \mathrm{T}$. & 25 & $\mathrm{~F}$ & $\begin{array}{l}\text { Postoperative } \\
\text { Hypoparathyroidism }\end{array}$ & 9.4 & 8.1 & 7.8 & 8.1 & 8.1 & $\infty$ \\
\hline 2 & M. S . & 34 & $\mathbf{M}$ & " & 7.0 & 6.0 & 6.2 & 6.3 & 6.3 & 10.0 \\
\hline 3 & M. Y. & 36 & $\mathrm{~F}$ & " & 8.0 & 7.1 & 7.0 & 7.4 & 7.1 & $\infty$ \\
\hline 4 & I .M. & 56 & $\mathrm{~F}$ & " & 7.2 & 5.4 & 5.1 & 5.9 & 5.3 & $\infty$ \\
\hline 5 & K.S. & 52 & $\mathrm{~F}$ & " & 7.0 & 5.8 & 6.2 & 6.3 & 6.2 & 9.0 \\
\hline 6 & S.N. & 20 & $\mathrm{~F}$ & " & 9.7 & 7.2 & 8.1 & 7.9 & 7.1 & $\infty$ \\
\hline 7 & $\mathrm{~T} . \mathrm{K}$. & 38 & M & $\begin{array}{l}\text { Idiopathic } \\
\text { Hypoparathyroidism }\end{array}$ & 7.3 & 6.0 & 6.2 & 6.1 & 6.2 & 19.5 \\
\hline 8 & H.N. & 20 & $\mathrm{~F}$ & " & 7.6 & 6.2 & 6.3 & 6.3 & 6.5 & 14.0 \\
\hline 9 & T.Y. & 38 & $\mathrm{~F}$ & " & 8.5 & 6.5 & 7.1 & 7.2 & 7.6 & 5.3 \\
\hline 10 & M. I . & 13 & $\mathrm{~F}$ & " & 8.5 & 7.5 & 7.8 & 8.2 & 8.4 & 2.8 \\
\hline
\end{tabular}

Table 2. Relovery of Serum $\mathrm{Ca}$ in $\mathrm{Na}_{2}$-EDTA Test (Hypoparathyroidism) 
Table 3. Ghange of Serum Parathyroid Hormonn (PTH) in $\mathrm{Na}_{2}$-EDTA Test (Normal Subjects)

\begin{tabular}{|c|c|c|c|c|c|c|c|c|c|c|c|}
\hline \multirow{2}{*}{$\begin{array}{l}\text { Case } \\
\text { No. }\end{array}$} & \multirow{2}{*}{ Name } & \multirow{2}{*}{ Age } & \multirow{2}{*}{ Sex } & \multirow{2}{*}{ Diagnosis } & \multicolumn{5}{|c|}{ Serum PTH ng/ml } & \multirow{2}{*}{$\begin{array}{c}\text { Max } \\
\text { rise } \\
\%\end{array}$} & \multirow{2}{*}{$\begin{array}{c}\text { Max } \\
\text { rise } \\
\mathrm{ng} / \mathrm{ml}\end{array}$} \\
\hline & & & & & Before & $5 \mathrm{~min}$ & $60 \mathrm{~min}$ & $\mid \begin{array}{c}120 \\
\min \end{array}$ & $\begin{array}{c}180 \\
\min \end{array}$ & & \\
\hline 1 & $\mathrm{~T} . \mathrm{S}$. & 62 & F & Normal & 0.3 & 1.0 & 0.7 & 0.6 & 0.2 & 330 & 0.7 \\
\hline 2 & I. S . & 71 & F & " & 0.4 & 0.4 & 0.5 & 1.0 & 1.5 & 250 & 0.6 \\
\hline 3 & Y.M. & 60 & M & " & 0.3 & 1.0 & 0.4 & 0.3 & 0.3 & 330 & 0.7 \\
\hline 4 & M.U. & 64 & M & " & 0.2 & 1.2 & 1.2 & 0.4 & 0.2 & 600 & 1.0 \\
\hline 5 & Y.H. & 61 & M & " & 0.4 & 1.2 & 1.0 & 1.0 & 0.8 & 300 & 0.8 \\
\hline 6 & Y.A. & 50 & M & " & 0.4 & 1.4 & 1.0 & 0.8 & 0.2 & 350 & 0.6 \\
\hline 7 & M.K. & 50 & M & " & 0.5 & 2.1 & 1.3 & 1.0 & 0.6 & 420 & 1.6 \\
\hline 8 & K. I . & 48 & M & " & 0.4 & 2.0 & 1.8 & 1.2 & 0.8 & 500 & 1.6 \\
\hline 9 & T.N. & 36 & M & " & 0.6 & 1.5 & 1.3 & 1.0 & 0.7 & 250 & 0.9 \\
\hline 10 & S.A. & 37 & M & " & 0.3 & 2.4 & 2.0 & 1.2 & 0.5 & 800 & 2.1 \\
\hline 11 & S.U. & 37 & M & " & 0.4 & 3.0 & 2.1 & 1.4 & 0.6 & 750 & 2.6 \\
\hline 12 & M.Y. & 28 & M & " & 0.2 & 1.9 & 1.6 & 1.0 & 0.4 & 950 & 1.7 \\
\hline 13 & M. F. & 20 & $\mathbf{M}$ & " & 0.3 & 2.8 & 2.0 & 1.5 & 0.6 & 930 & 2.5 \\
\hline 14 & T.N. & 23 & M & " & 0.5 & 3.0 & 2.2 & 1.4 & 0.7 & 600 & 2.5 \\
\hline \multicolumn{4}{|c|}{ Mean \pm S.E.M. } & & $\left|\begin{array}{c}0.4 \pm \\
0.02\end{array}\right|$ & $\begin{array}{c}1.8 \pm \\
0.21\end{array}$ & $\begin{array}{c}1.3 \pm \\
0.16\end{array}$ & $\begin{array}{c}1.0 \pm \\
0.09\end{array}$ & $\left|\begin{array}{c}0.5 \pm \\
0.05\end{array}\right|$ & $520 \pm \frac{ \pm}{70}$ & $\begin{array}{c}1.4 \pm \\
0.20\end{array}$ \\
\hline
\end{tabular}

Table 4. Change of Sernm Parathyroid Hormone (PTH) in $\mathrm{Na}_{2}$-EDTA Test (Normal subjects)

\begin{tabular}{|c|c|c|c|c|c|c|c|c|c|c|c|}
\hline \multirow{2}{*}{$\begin{array}{l}\text { Case } \\
\text { No. }\end{array}$} & \multirow{2}{*}{ Name } & \multirow{2}{*}{ Age } & \multirow{2}{*}{ Sex } & \multirow{2}{*}{ Diagnosis } & \multicolumn{5}{|c|}{ Serum PTH } & \multirow{2}{*}{$\begin{array}{c}\text { Max } \\
\text { rise } \\
\%\end{array}$} & \multirow{2}{*}{$\begin{array}{c}\operatorname{Max} \\
\text { rise } \\
\mathrm{ng} / \mathrm{ml}\end{array}$} \\
\hline & & & & & Before & $5 \mathrm{~min}$ & $60 \mathrm{~min}$ & 120 min & $\mid \begin{array}{c}180 \\
\min \end{array}$ & & \\
\hline 1 & $\mathrm{~K} . \mathrm{T}$. & 25 & $\mathrm{~F}$ & $\begin{array}{l}\text { Postoperative } \\
\text { Hypoparathyroidism }\end{array}$ & $<0.15$ & $<0.15$ & $5<<0.15$ & $<0.15$ & $5<0.15$ & 0 & 0 \\
\hline 2 & M.S. & 34 & M & " & $<0.15$ & $<0.15$ & $5<<0.15$ & $<0.15$ & $5<0.15$ & 0 & 0 \\
\hline 3 & M.Y. & 36 & $\mathrm{~F}$ & " & $<0.15$ & $<0.15$ & $5<0.15$ & $<0.15$ & $5<0.15$ & 0 & 0 \\
\hline 4 & I.M. & 56 & $\mathrm{~F}$ & " & $<0.15$ & $<0.15$ & $5<0.15$ & $<0.15$ & $5<0.15$ & 0 & 0 \\
\hline 5 & K. S . & 52 & F & " & $<0.15$ & $<0.15$ & $5<0.15$ & $<0.15$ & $5<0.15$ & 0 & 0 \\
\hline 6 & S.N. & 20 & $\mathbf{F}$ & " & $<0.15$ & $<0.15$ & $5<0.15$ & $<0.15$ & $5<0.15$ & 0 & 0 \\
\hline 7 & $\mathrm{~T} . \mathrm{K}$. & 38 & $\mathbf{M}$ & $\begin{array}{l}\text { Idiopathic } \\
\text { Hypoparathyroidism }\end{array}$ & $<0.15$ & $<0.15$ & $5<0.15$ & $<0.15$ & $5<0.15$ & 0 & 0 \\
\hline 8 & H.N. & 20 & $\mathrm{~F}$ & " & $<0.15$ & $<0.15$ & \begin{tabular}{l|l}
5 & 0.3
\end{tabular} & 0.3 & 0.2 & + & 0.3 \\
\hline 9 & T.Y. & 38 & $\mathrm{~F}$ & " & $<0.15$ & $<0.15$ & $5<<0.15$ & $5<0.15$ & $5<0.15$ & 0 & 0 \\
\hline 10 & M. I . & 13 & $\mathrm{~F}$ & " & $<0.15$ & $<0.15$ & $5 \mid<0.15$ & $<0.15$ & $5<0.15$ & 0 & 0 \\
\hline
\end{tabular}

示す如く, 術後副甲状腺機能低下症では 6 例の全例で，血清カルシウムの回復は全く見られないか又は明ら かに遅延し，4 例の特発性副甲状腺機能低下症では 2 例は期待回復時間の延長をみとめたが，2 例では延長 はみとめられなをつた，後の 2 例ではビタミンDによる治療を既に行つており，てのてとが骨の反応性を回 復させた結果，回復時間が短縮されたのではないかと思われる.

表 3 . 及び表 4 には $\mathrm{Na}_{2}$-EDTA 試験に於て血中副甲状腺ホルモンの変動を示すが，正常者では血中副甲 状腺ホルモンは投与前の $0.4 \pm 0.02 \mathrm{ng} / \mathrm{ml}$ から $\mathrm{Na}_{2}$-EDTA 投与直後に $1.8 \pm 0.21 に 上$ 界し，その後次第に低 
下して投与前値に回復するととが見られる．同時に血中カルシウムの回復と血中副甲状腺ホルモンの上昇の 測定を行つた 7 例では血中副甲状腺ホルモンの上昇度の高い程期待回復時間は石い傾向がみとめられた。

\section{考按}

先に報告された EDTA-Ca- $\mathrm{Na}_{2}$ による血清カルシウムの低下による副甲状腺機能検查は EDTA-Ca-Na $a_{2}$ の投与最に比べて血清カルシウムの低下が著明でなく, 又製品による効果の差が見られるので, 血清カルシ ウム下降能に於て再現性の高いEDTA- $\mathrm{Na}_{2}$ の方が適当であると考光られる. 即ち EDTA のキレート能は 1 価の金属 2 ケ又は 2 価の金属 1 ケが確実であり, 原子最の大きいもの程キレート結合力が強いので, Ca はNa２ケの代りに EDTA と結合するととが容易であるが，EDTA-Ca-Na $\mathrm{Na}_{2}$ の $\mathrm{Na}_{2}$ が更に Ga をキレー 卜結合して EDTA-Ca 2 となるてとは困難であつて鉛その他のカルシウムより原子最の大きい金属は Ca の 代りに EDTA と結合するてとが出来るので, EDTA-Ca-Na 2 は鉛中毒その他の重金属中毒で血中重金属レ ベルを低下させるには便利であるが，血清カルシウムを低下させる副甲状腺機能検查には必ずしも適当では ないと思われる。しかしながら EDTA-Ca-Na $2_{2}$ は全く血管痛を起さないのに比べて EDTA-Na をおてすので大量のプロカインとともに点滴投与するととが必要であり, 現在迄にプロカインの副作用はみ とめていないが心疾患その他の場合には注意すべきてとであろう.

EDTA による低カルシウム血症が副甲状腺ホルモンの分泌を刺激するととは確かであり, 副甲状腺機能 正常者では EDTA による血清カルシウムの低下とともに血中副甲状腺ホルモンが上昇し, てれが骨からカ ルシウムを動員して血中カルシウムを回復せしめると考えられる。従つて若し副甲状腺ホルモンの分泌能が 低下している場合には血中副甲状腺ホルモンの上昇は見られず，又血清カルシウムの回復も遅れることが期 待される. 本研究に於ても術後及び特発性副甲状腺機能低下症では大部分血清カルシウムの回復は正常者に 比して明らかな遅延を示したが，既に治療を行つていた 2 例の特発性副甲状腺機能低下症ではての様な延長 は見出されず，血清カルシウムの回復に関しては正常者との間に差を見出すととは出来なかつた。しかし乍 らての 2 例を含めて血中甲状腺ホルモンが正常值まで回復したものはなかつた．即ち EDTA 投与後の血清 カルシゥムの回復は副甲状腺ホルモンの分泌充進を介するものだけではなく, 副甲状腺機能低下症でビタミ ンD治療により血清カルシウムが正常化したものでは血中副甲状腺ホルモンの上昇を見るととなく，血清カ ルシウムの回復は正常に見られたととは副甲状腺ホルモンの分泌を介しない機序も存在するととを示唆する ものである．検查方法としては従つて血清カルシウムの回復をみるだけでは副甲状腺機能検查法としての特 異性は充分でなく， EDTA によつて低カルシウム血症をおてさせ，てれに対する血中副甲状腺ホルモンの 分泌の変化をみるととがもつともよい方法であろうと考えられる.

EDTA によつて血清カルシウムを低下せしめてカルシウム代謝を検討しょうとするててろみは Kaiser 等 $^{6}$ 亿初まりその後 Jones ${ }^{7) 8)}$ Meltzer 等によつて行われ，副甲状腺㙨能低下症の診断して有用であるとされ， ことに甲状腺手術後などに見られる血清カルシウムは正常範囲にとどまる所謂不全形の副甲状腺機能低下症 ではととにその診断価値は大きいとされる，確かに血清カルシウルの著明な低下とテタニーその他の症状を 示す副甲状腺機能低下症では EDTA を投与して更に血清カルシウムを低下させてテタニーを誘発したり悪 化したりしなくても彭断は容易であり，明確な重症の副甲状腺機能低下症には EDTA 試験は必要性が少な いといえる．しかし乍ら軽症の血清カルシウムの低下があまり著明でない潜在性副甲状腺機能低下症，又治 療がある程度行われた結果部分的に血清カルシウム及び症状の改善を示した例に於て診断を確定するてとが 必要な場合もしばしばあり，ての様な場合には血清カルシウムを EDTA によつて $2 \mathrm{mg} / \mathrm{d}$ 程度低下せしめ てもテタニーその他不快な装状を誘発する危険がなく， EDTA 試験がもつともその効果を示すと思われる. 従来は血清カルシウムの回復だけを測定してきたがこれに洫中副甲状腺ホルモンの radioimmunoassay を 併用するてとにより, 特異的な副甲状腺機能予備能の試験を行うことが出来ればその有用性は一㬝増すとと が期待される. 又血清カルシウムの回復は EDTA によつて著明な低下をおてさせた場合には20時間にわた つて経過を追うことが必要な場合もあるが，我々の検討による 3 時間で正常者と副甲状腺機能低下症患者と 
の間に差がみとめられ, ととに副甲状腺ホルモンの血中濃度を測定する場合には比較的短時間で変化がみら れ， 3 時間で略々投与前置に回復するととが明きらかである．尚プロインの静注のみでは血清カルシウムの 変化はみとめられなかつた。

\section{総 括}

$\mathrm{Na}_{2}$-EDTA をプロカインとともに静注すると血清カルシウムは明暸に低下するとともに血管痛をある程 度避けるととが出来, 血清カルシウムの回復と血清副甲状腺ホルモンの上昇を測定するてとによつて副甲状 腺ホルモン分泌予備能を検查するととが可能であり， $\mathrm{Ca}-\mathrm{Na}_{2}$-EDTA よりも血清カルシウムの低下は著明且 つ再現性があるものと思われた。

\section{謝 辞}

恩師吉川政己教授の御指導, 東京都養育院折茂㹈博士, 浅草国際病院峰三夫院長の御協力, 研究助手金井 伸江学士の技術的御援助を感謝する。

\section{文献}

1) 藤田拓男, 折茂 肇: 日本内分泌学会雑誌, $46: 73$ (1970),

2）藤田拓男, 折茂 肇, 大畑雅 洋, 岡野一年: 日本内分泌学会雑誌, $47: 181$, (1971).

3) Fujita, T., Orimo, H., Okano, K., Yoshikawa, M., Inoue, T., Itami, Y : Endocrinol. Jap. 19 : 571, (1972)

4) Fujita,T., Orimo, H., Yoshikawa, M. : Endocrinologia Jap. 13 : 338, (1966).

5）折茂 肇, 藤田拓男, 吉川政己：日本 臨床, $23: 143$, (1965).

6) Kaiser, W., Ponsold, W. : Klin. Wochenschr. 37 : 1183, (1959).

7) Jones, K.H., Fourman, P. : Lancet $2: 119$, (1963)

8) Jones, K.H., Fourman, P. : Lanot 2 :

121, (1963)

9) Meltzer, L.E., Kitchell, J.R., Palmer, F. : Amer. J. Med. Sci., 242 : 11, (1961) 